\title{
Authentic Materials to Foster Writing Skills in College EFL Learners
}

\author{
Mercedes Chamba ${ }^{1}$, Martha Reinoso ${ }^{1} \&$ Elena Rengifo ${ }^{1}$ \\ ${ }^{1}$ Pontificia Universidad Católica del Ecuador, Ecuador \\ Correspondence: Elena Rengifo, Facultad de Comunicación, Lingüística y Literatura, Escuela de Lenguas, \\ Pontificia Universidad Católica del Ecuador, Quito, Ecuador.
}

Received: April 3, 2019 Accepted: May 14, 2019 Online Published: May 16, 2019

doi: 10.5539/elt.v12n6p112 URL: https://doi.org/10.5539/elt.v12n6p112

\begin{abstract}
Since it is a productive skill, writing is considered one of the most crucial abilities in communication; nonetheless, EFL learners have difficulty composing texts which are both communicatively and linguistically competent. This study intends to explore the benefits of using authentic materials in EFL learners, with an emphasis on writing skills. To pursue this objective, fifty-two participants were chosen randomly from a B1 level (following the Common European Framework of Reference for Languages). The participants were distributed into two groups: an experimental group and a control group. The students were majoring in various degrees at the Pontifical Catholic University of Ecuador (PUCE). In this case study, in which the application of authentic materials covered fifty percent of daily two-hour classes, data was collected through a structured pre-test, a post-test, and an opinion survey. All data was analyzed using a rubric designed for this purpose. This research, which is based on the Communicative Language Teaching Approach, also deals with various concepts regarding authentic materials and researchers' perceptions. The findings elicited positive results for students' writing skills with the use of authentic materials and shed lights on participants' opinions.
\end{abstract}

Keywords: authentic resources, communicative approach, English writing competence, language acquisition

\section{Introduction}

This study is based on the Communicative Language Teaching approach (CLT), which emphasizes the importance of using authentic and meaningful communication in classroom activities (Richards and Rodgers, 2001). Under this approach, students acquire communicative competence; that is, the ability to "use the appropriate language in a given real-life like context, and to make themselves understood by communicating efficiently, while establishing at the same time the process of negotiating meaning with the listener" (Adam et al., 2010, p. 432). In such a context, "exposing the students to authentic materials throughout the teaching process is crucial" (Adam et al., 2010, p. 431). Furthermore, this exposure is vital if we take into account the inclusion of communicative competence in the Common European Framework of Reference (CEFR), a tool that has been adopted by many Ecuadorian institutions "for establishing guidelines in terms of the objectives and competencies that a student of English must acquire upon finishing their university education" (Harutyunyan \& Poveda, 2018, p. 138).

\subsection{Statement of the Problem}

In various settings, English as a foreign language serves as the principal means of communication among citizens from different linguistic backgrounds. From a statistical point of view, English is one of the world's most spoken languages (Jason, 2011), and as such, many people have taken up learning it. There are several teaching strategies and materials to help students excel in the EFL classroom, yet learners have a difficult time exchanging their thoughts in English.

In addition to students' problems learning English, the Ecuadorian educational system has decided to implement it as a foreign language in the curricula (Educación, 2016). Most students start learning the language in primary school and continue studying it through college. At the PUCE, students must reach a B2 level of English as a requirement for graduation. Despite being immersed in an EFL classroom, learners still fail to achieve the level necessary for successful communication in English.

When learners attempt to exchange information in English, either in written or spoken form, they struggle with using it as a vehicle for communication. The EF English Proficiency Index placed Ecuador \#65 out of 88 countries (EF-EPI, 2018), which is considered a low level. This indicates an urgent need to implement strategies to solve the problem. One of these strategies could be exposure to input provided by authentic resources in the EFL classroom, 
so that students are familiar with the kind of information, language, and style contained in these types of resources. Indeed, we must ensure that the materials are as authentic as possible while pursuing the skills and subskills students need to foster $(\mathrm{Al}, 2003)$.

In this case study, we are only focusing on writing skills, and more specifically on investigating how coherent and cohesive students' texts can be after using authentic material in the class. This is due to the fact that each language skill (listening, reading, speaking and writing) has its own features, and we think it is best to study these separately and one-by-one.

\section{Literature Review}

\subsection{Authentic Material}

Since we are dealing with authentic material, it is important that this be defined. An authentic text is one "created to fulfill some social purpose in the language community in which it was produced" (Little et al., 1988 as cited in Guariento \& Morley, 2001, p. 347). It is prepared for native speakers without teaching objectives (Martinez, 2002 as cited in Al Azri \&Al-Rashdi, 2014). It can be "written or oral material containing 'real,' not processed language, produced by a real speaker for a real audience and in a real situation" (Adam et al., 2010, p. 432). In short, authentic materials are texts that have been created for genuine communicative purposes (Mishan, 2005). However, "authentic texts in the context of language learning, means any source of information used to help learners to develop an authentic understanding" (Breen, 1985 as cited in Al Azri \&Al-Rashdi, 2014, p. 250).

Gebhard 1996 (as cited in Belet Boyaci, 2018) grouped authentic materials under three categories. Authentic audio/visual materials include TV commercials, quiz shows, video clips, cartoons, movies, soap operas, and radio dramas and commercials. Authentic visual materials include slides, pictures, photographs, children's drawings, non-verbal street signs, skylines, magazine pictures, postcards, nonverbal picture books, and stamps. Authentic written materials are newspaper articles, movie commercials, astrology columns, sports news reports, obituaries, advice columns, lyrics, restaurant menus, street signs.

It is likewise important to note that a large amount of the materials mentioned by Gebhard (1996) are now easily available online. Arianie (2017) states that "the Internet is regarded as a very important and rich source for authentic material" (p. 117).

Authentic material has been widely used to help students learn a foreign language, and its use in EFL classes is not new. Teachers began using authentic materials in the 1970s as a result of the spread of the CLT approach (Hedge, 2000 as cited in Al Azri \& Al-Rashdi, 2014). The emphasis of this language teaching approach on real-world communication has made it imperative to provide students with the skills required to accomplish real-world tasks. As Arnold 1991 (as cited in Joy, 2011, p. 237) notes, "the more authentically the classroom mirrors the real world, the more real the rehearsal will be and the better the learning and transfer will be." According to Edge (1994, as cited in Chamba \& Gavilanes, 2018) there are two main qualities that make authentic material appropriate for classroom use. One is the linguistic feature, since it represents the actual learning objective. The other is the motivational factor, because it connects language learning's means and objective. In other words, authentic material gives significance to the learning process and increases the students' motivation by transferring course knowledge to their daily lives (Chamba \& Gavilanes, 2018). It should also be added that authentic texts per se are "intrinsically more active, interesting and stimulating" than textbooks (Lee,1995; Little, Devitt \& Singleton, 1988; Peacock, 1997; Shei, 2001 as cited in Al Azri \&Al-Rashdi, 2014, p. 249).

\subsection{Advantages and Disadvantages of Authentic Materials}

Guariento \& Morley, 2001; Wilcox \& Oaks, 1999; Weyers, 1999 (as cited in Al Azri \& Al-Rashdi, 2014) state that using authentic materials has linguistic and non-linguistic advantages. At the linguistic level, authentic material has positive effects on learners because it helps them produce better language. It should also be noted that "there is a wide choice of styles, genres and formality in authentic texts. One piece of text may be used for various activities and tasks" (Martinez, 2002, as cited in Nematollahi \& Maghsoudi, 2015, p.113).

In addition to the linguistic advantages, authentic material also has certain non-linguistic advantages; it contains cultural traits based on the intended use, and the context in which they are used. Introducing learners to this natural use of the language attracts their interest and increases positive motivation (Belet Boyaci, 2018). Furthermore, authentic material offers significant exposure to real language, increases motivation in learners, and gives them the opportunity to develop communicative skills (Tomlinson, 2012, as cited in Chamba \& Gavilanes, 2018). Its importance also lies in the fact that "it is a window into culture" (Sherman, 2003, as cited in Al Azri \& Al-Rashdi, 2014, p. 252). As Martínez (2002) puts it, authentic material may be "inspirational for some students" (as cited in Nematollahi \& Maghsoudi, 2015, p. 113). 
On the other hand, there are some arguments against its use. There is no significant difference between students using authentic texts and those who use only textbooks (Kienbaum et al., 1986 as cited in Al Azri \& Al-Rashdi, 2014). Authentic texts are "too difficult and time consuming to select, edit and prepare" (Miller, 2005, as cited in Al Azri \& Al-Rashdi, 2014, p. 252). The authentic text may be difficult to understand because the student and the text belong to different cultural backgrounds. It may quickly become obsolete. It may not be what the students need (Martinez, 2002 as cited in Nematollahi \& Maghsoudi, 2015). Kim 2000 has stated that, "authentic materials can be used with intermediate and advanced level students only" (as cited in Joy, 2011, p.13). Language learners at lower levels may find it difficult to process all the linguistic input found in authentic texts. Researchers who are against the use of authentic materials with beginners feel that "authentic texts may not only be too lexically and syntactically complex, but also too conceptually and culturally dense for successful understanding" (McLaughlin, 1987; McLaughlin, Rossman, \& McLeod, 1983; Shook, 1997; Young, 1999, as cited in Crossley, Louwerse, McCarthy, \& McNamara, 2007, p. 5). Studies suggest that unwanted complexities in the text would unnecessarily frustrate, confuse, and demotivate students (Guariento \& Morely, 2001).

\subsection{Writing Skill}

Following speaking, writing is one of the two productive skills in English learning. Sundana (2017) states that "some research findings have indicated that the students' writing ability is yet far from satisfaction" (p. 81). It is complicated for students, and it is the hardest skill (Alwasilah, 2007, as cited in Sundana, 2017). However, it can be taught, if the teaching is supported by the correct tools (Feez and Joyce, 2000 as cited in Sundana, 2017). In her study, Katilie (2003, as cited in Sundana, 2017) found that the undesirable results in written English composition was because there was a failure to use appropriate teaching strategies in the class. One of these tools is the employment of authentic material in the classroom. Sundana (2017) found in his study that after incorporating this material, students' writing improved in terms of organization, the use of the appropriate grammar and vocabulary, and in aspects of content. Furthermore, students felt that the use of authentic materials helped them in writing since it gave them writing ideas and increased their vocabulary; consequently, they became more interested in writing. Having students read an email written by a foreign friend and composing a response helps students to deal with authentic resources in real life and learn useful communicative expressions (Yuhong, 2012). Learners must be exposed to all types of authentic materials in order to see profound improvement in this skill (Abdul, Rahman, Sabri, \& Shukri, 2017). This research's primary objective is thus to verify the effectiveness of authentic materials on EFL learners' writing skills at the university level, considering coherence and cohesion in their written texts.

\subsubsection{Coherence vs. Cohesion}

According to Bublitz, Lenk, \& Ventola (1997), coherence refers to a group of sentences that are logically connected to one other. In other words, sufficient background knowledge is provided for the receiver to be able to interpret the text. Tanskanen (2006) says that coherence is also more subjective, and thus receivers may perceive it in different ways. Hinkel (2003) adds that coherence is the organization of discourse in which all the elements fit together logically.

Tanskanen (2006) states that cohesion is the relation of meaning within a passage, which defines it as an idea. It is most likely connected to the grammatical and lexical aspects that construct a text. Similarly, Creme \& Lea (2008) view cohesion as words that fit together so that everything makes sense. Cohesion can be considered at different levels, such as connection between topics, themes, words and phrases. Hinkel (2003) claims that cohesion relates to the connection of sentences and paragraphs: in other words, it refers to the connectivity of ideas and sentences.

It is worth indicating that coherence and cohesion have a role to play because they contribute to the unity of discourse (Tanskanen, 2006). Both are thus considered in this research. Coherence refers to a text's relevance and clarity/organization, while cohesion represents mechanics: spelling, punctuation, and capitalization; vocabulary and grammar; subject verb agreement, verb tense, and missing words.

\section{Research Design}

\section{1 Research Type}

The purpose of this study was to investigate the impact of the use of authentic material in the acquisition of writing skills in the English learning classroom. Research was guided by the following questions:

a. Does the use of varied authentic material improve students' ability to write cohesive texts?

b. Does the use of varied authentic material enhance the students' coherence when writing? 
c. Do the students like to use authentic materials in the EFL classroom?

\subsection{Research Participants}

Fifty-two college-level students from levels four and five of the PUCE English Language Program participated in the study. The students were pursuing a variety of majors and must take English in order to graduate. Levels four and five are considered pre-intermediate and intermediate language levels, respectively, and correspond to a B1 level under the Common European Framework of Reference for Languages. Ten level four students and sixteen level five students were part of the control group during the first cycle of intensive courses in the first semester of the 2018 academic year. Equal numbers of level four and level five students were part of the experimental group during the second cycle of intensive courses in the First Semester of the 2018 academic year.

In the fifth week, all participants were asked to answer an anonymous survey with four sections to determine their opinions on the use of authentic resources to foster their writing skills. In the first part of the survey, learners had to indicate a number to express their degree of improvement, with five being the highest and one the lowest. In the second part, the participants were required to complete a chart using numbers from one to five, regarding the level of improvement in their writing skills. In the following section, they had to include comments explaining the type of activities and materials they liked and why. On the final section of the survey, the participants had to describe the exercises that they did not enjoy at all.

\subsection{Data Collection}

A writing production evaluation rubric with two sections was elaborated: one section was dedicated to communicative competence, which included relevance and clarity/organization (graded criteria). Relevance refers to the notion, which is central to the judgments made by the academic reader about the selection and presentation of information (Lawe Davies, 1999), while clarity/organization refers to the ability to communicate effectively with well-constructed sentences and precise word choice (Nordquist, 2018). The other section was dedicated to linguistic competence, which included mechanics like spelling, punctuation, and capitalization; vocabulary (word choice); grammar (subject verb agreement), verb tense, and missing words (criteria for number of errors). A list of editing symbols was also adopted to provide feedback regarding students' writing. For each level, a pre-test and a post-test were given at the beginning and ending of the course, with the two tests being the same. The same evaluation was administered in the control and experimental groups in each level.

A wide variety of communicative activities with authentic material were elaborated for each level. This included verbal and visual material, such as newspaper and magazine articles, news, poems, songs, TV commercials, cartoons, movie segments, etc.

The engage, study, activate (E.S.A.) methodology was used in each activity. All activities had a pre-writing, writing, and post-writing activity as demonstrated in the research conducted by Krasnikova (2014) who studied the use of films as authentic resources to teach ESL writing, and who used previewing, viewing, and post-viewing activities. In this research, participants worked on prewriting activities, which involved brainstorming for activation, predicting, eliciting vocabulary, talking about personal experiences, identifying characters' names, guessing the meaning of vocabulary words, answering the given questions, and introducing new vocabulary and grammar. Some of the writing activities performed by students included taking notes, predicting the ending of a video or story, finding similarities and differences, summarizing, and expanding the text. The post-writing activities included summaries, surveys, speed writing, paragraph organization, responding to emails, recognizing specific grammar structures and vocabulary patterns, making comparisons, and practicing different genres of writing.

Finally, a survey to evaluate the students' perception of their own progress was administered. This survey was given to all the students in the experimental groups and included a quantitative section and an open-ended question section.

\subsection{Procedures}

During the beginning of the first semester of 2018, a pre-test was administered to the control group participants in the fourth and fifth levels of the first cycle intensive courses. Instruction was carried out using the last six lessons of the Cambridge textbook Empower B1 in level four, and the first five lessons of Empower B1+ in level five. In the last week of the cycle, a post-test, which was the same as the pre-test, was given to both groups.

Students in the second cycle intensive courses became part of the experimental groups. They were given the same pre-tests and post-tests administered to the students in the control group. During the course, $50 \%$ of the time was devoted to complying with the material regularly studied in these levels. Activities with authentic material were used for the other $50 \%$ of the time. 
All tests were evaluated with the rubric and editing symbols created for this purpose. At the end of the semester, data was collected in an Excel spreadsheet, and a descriptive and (inferential) statistical analysis was carried out in order to determine the influence of authentic material on the improvement of writing skills.

\section{Results and Discussion}

4.1 Quantitative Analysis

Table 1. Statistical analysis (level 4)

\section{LEVEL 4}

\begin{tabular}{llllll}
\hline Group & \multicolumn{2}{l}{ PRE-TEST } & \multicolumn{2}{l}{ POST-TEST } \\
\cline { 3 - 5 } & & $\begin{array}{l}\text { Clarity/ } \\
\text { Organization }\end{array}$ & Word Choice & Clarity/ & Word Choice \\
Control & Mean & 3.90 & 5.60 & 3.95 & 8.50 \\
Experimental & Mean & 4.00 & 11.50 & 4.80 & 8.60 \\
\hline
\end{tabular}

After analyzing the results of the pre-test in both the control and the experimental groups (Level 4), no statistically significant difference was found in the evaluation criteria used to grade the students' writing, and the only difference was in the "word choice" criteria. Due to these results, it can be stated that the experimental group had more vocabulary problems. These results do not affect the study since both groups had a similar level in most of the evaluation criteria.

Moreover, after analyzing the results of the post-test, there was no statistically significant difference between the control group and the experimental group. The results were similar except for the "clarity/organization" criterion. As shown in table 1, the experimental group was better than the control group in this parameter.

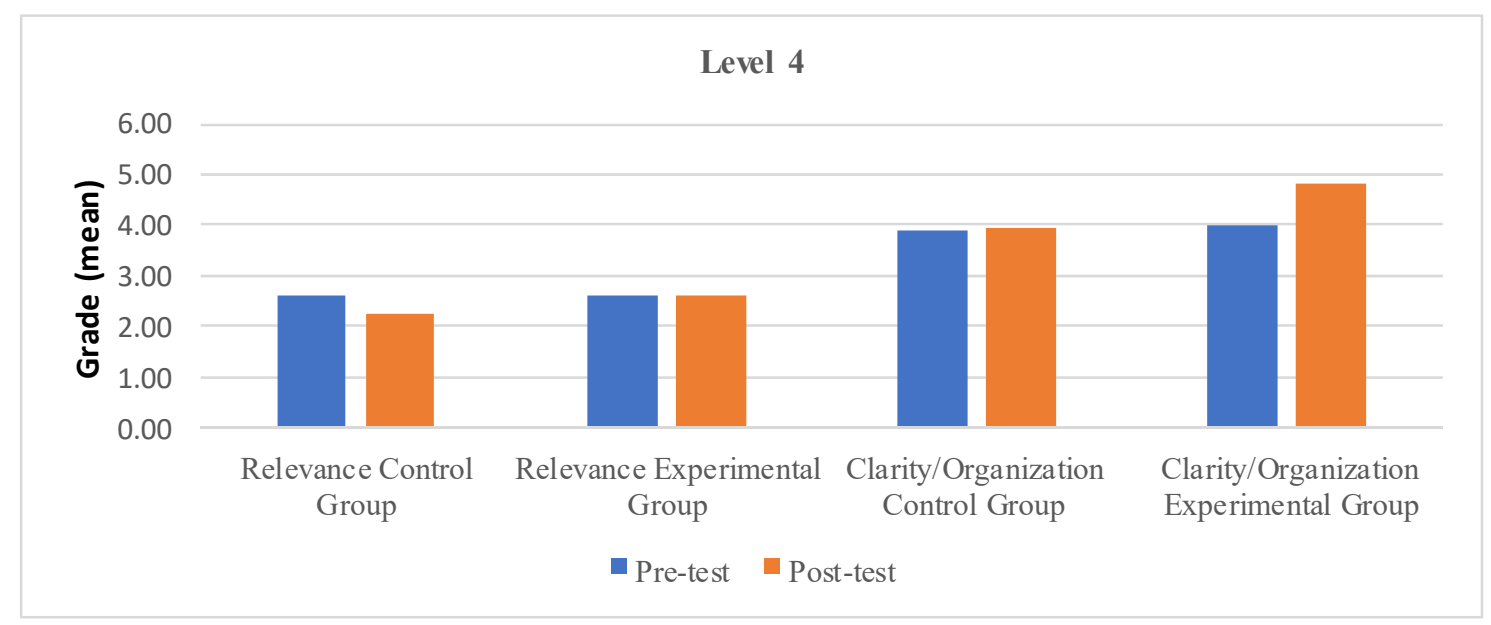

Figure 1. Communicative competence criteria (level 4)

Regarding the communicative competence evaluation criteria, we can see that there was improvement in the experimental group in the "clarity/organization" criterion (see Figure 1) which supports the idea that the use of authentic materials enhances pre-intermediate students' coherence when writing. 


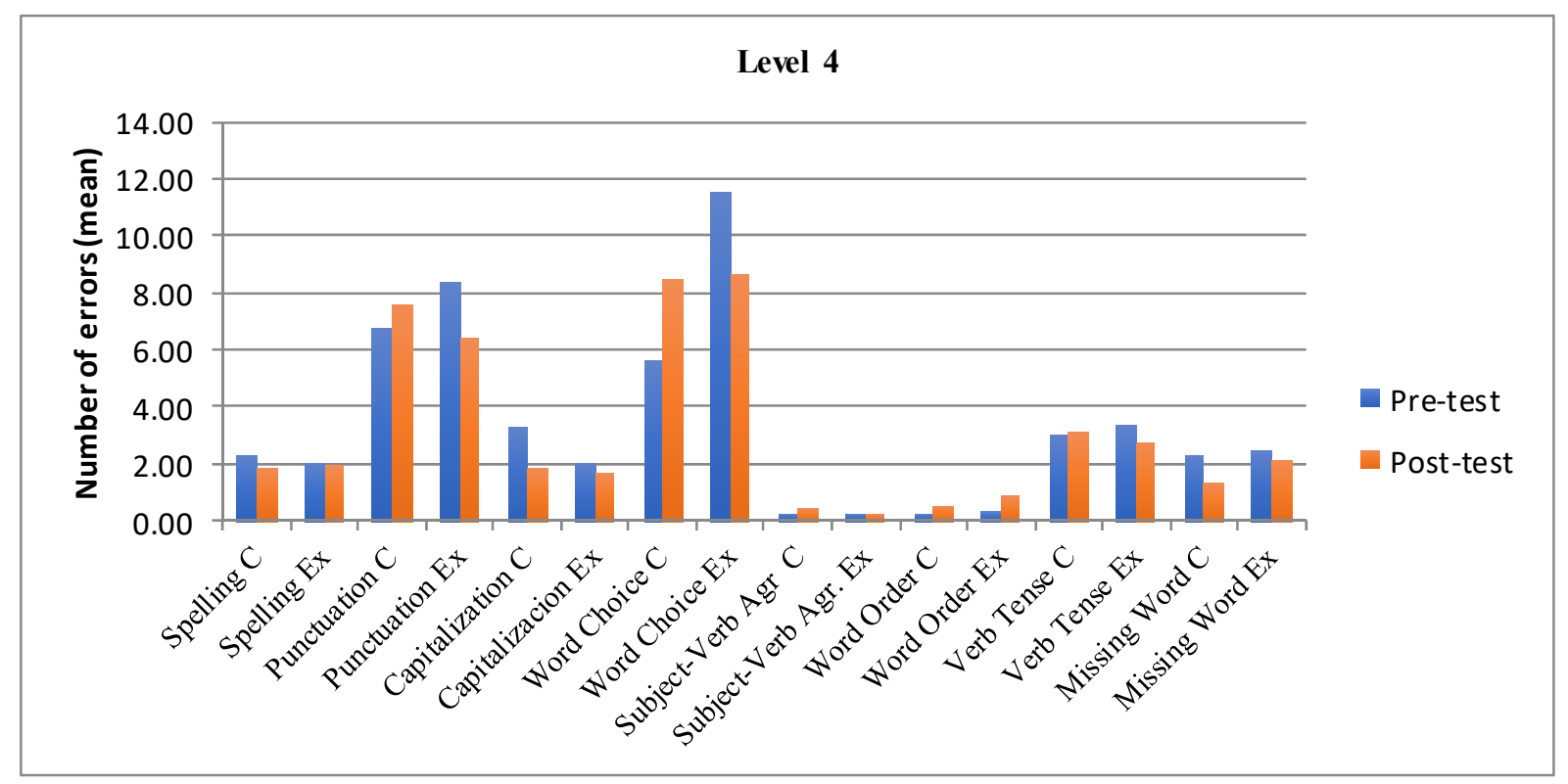

Figure 2. Linguistic competence criteria (Level 4)

Considering the linguistic competence evaluation criteria, it is possible to see that the number of errors in the "punctuation," "word choice" and "verb tense" criteria decreased; see Figure 2. Although these data do not show a statistically significant difference, it is possible to see that the use of authentic materials improves pre-intermediate students' ability to write cohesive texts, but not in all aspects involved in this subskill.

Below we can see a student's writing example where the "clarity/organization" criterion is improved. Moreover, the number of errors in "punctuation," "word choice" and "verb tense" decreased in the post-test compared with the pre-test.

Student's writing example:

Topic: Write a short composition (110 words) about a situation in your life when you felt frightened.

Pre-test:

I felt really frightened once time of my life when I was waking near of my house while six other mens were walking in front of me. This time was night at seven pm on Friday, I was returning of the university to go at my house.

The mens were thiefs and in this moment still me my smartphone, I tried to run but one man didn't can move me because he used a knife.

There weren't other people in the street to help me or call the police, anyone saw the situation. After the still, I speak with my brothers and neighbors and we used the car of my house to follow them.

I can't found my cell phone.

Post-test:

One day when I was eighteen years old, I was driving the car of my parents on a street far away of Quito. I had visited a place very interesting on Latacunga with my cousins who live there. But when I was returning at my house, I had a problem with the car, it didn't works. The car broke down in the middle of street and I had this problem at night.

I couldn't call anyone because I didn't have any battery for my cellphone, I felt really frightened. Fortunately, someone stopped his car and helped me to carry the car with an expert. Finally I could arrive at my house. 
Table 2. Statistical analysis (level 5)

LEVEL 5

\section{PRE-TEST}

\section{POST-TEST}

Group

\begin{tabular}{llllllll}
\hline & & Relevance & $\begin{array}{l}\text { Clarity/ } \\
\text { Organization }\end{array}$ & Spelling & Relevance & $\begin{array}{l}\text { Clarity/ } \\
\text { Organization }\end{array}$ & Spelling \\
Control & Mean & 3.69 & 5.28 & 2.88 & 2.94 & 4.91 & 2.25 \\
Experimental & Mean & 3.00 & 4.47 & 1.38 & 3.13 & 5.13 & 1.13 \\
\hline
\end{tabular}

After analyzing the pre-test results in both the control group and the experimental group (Level 5), a statistically significant difference was found for the "relevance," "clarity/organization," and "spelling" criteria. The relevance and clarity/organization scores were better in the control group. On the other hand, the number of spelling mistakes was higher in the control group. These results do not affect the study, since both groups had a similar level in most of the evaluation criteria (see Appendix 3).

Furthermore, after analyzing the results of the post-test, improvement was found in the experimental group for most of the evaluation criteria. However, there was no statistically significant difference between the control and experimental groups, as shown in Table 2 and Appendix 4.

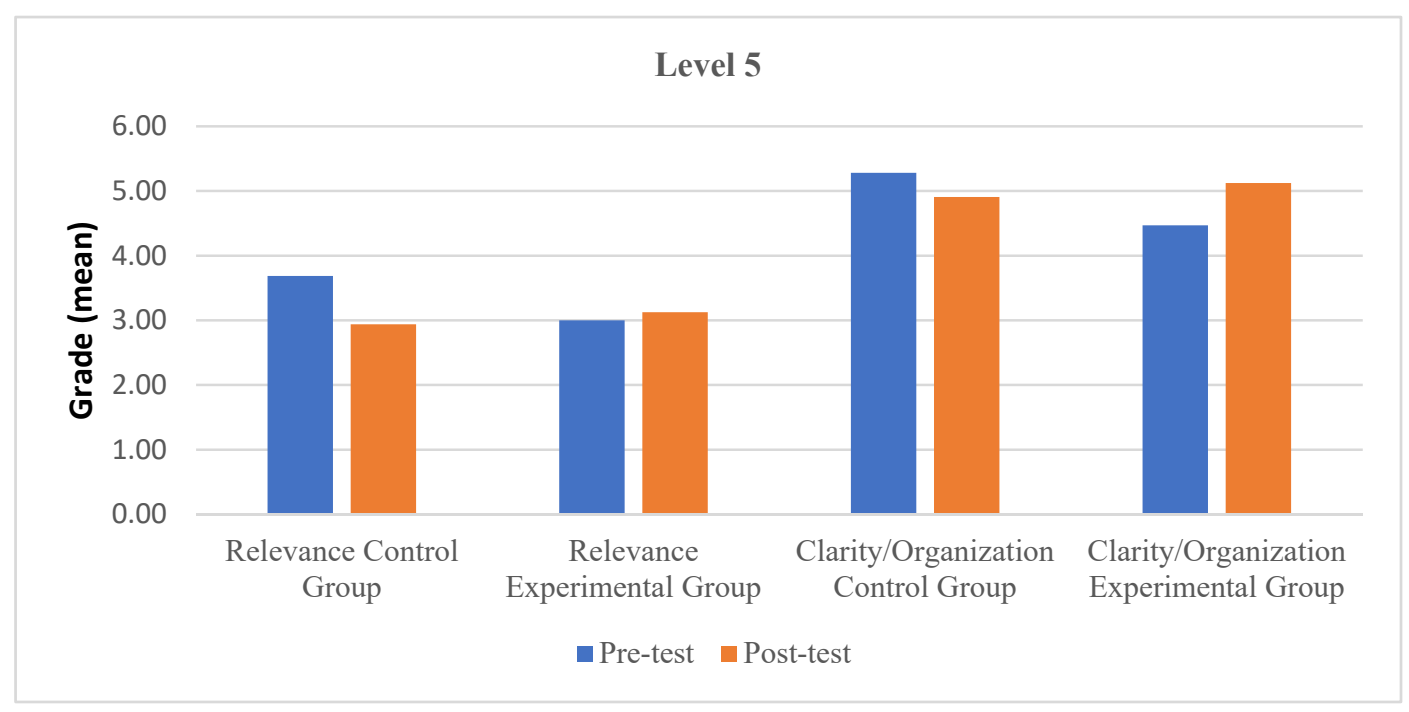

Figure 3. Communicative competence criteria (level 5)

As regards the evaluation criteria for communicative competence, we can see that there was an improvement in the experimental group in the "relevance" and "clarity/organization" criteria; see Figure 3. This shows us that the use of authentic materials improves intermediate students' coherence when writing, but not with a statistically significant difference. 


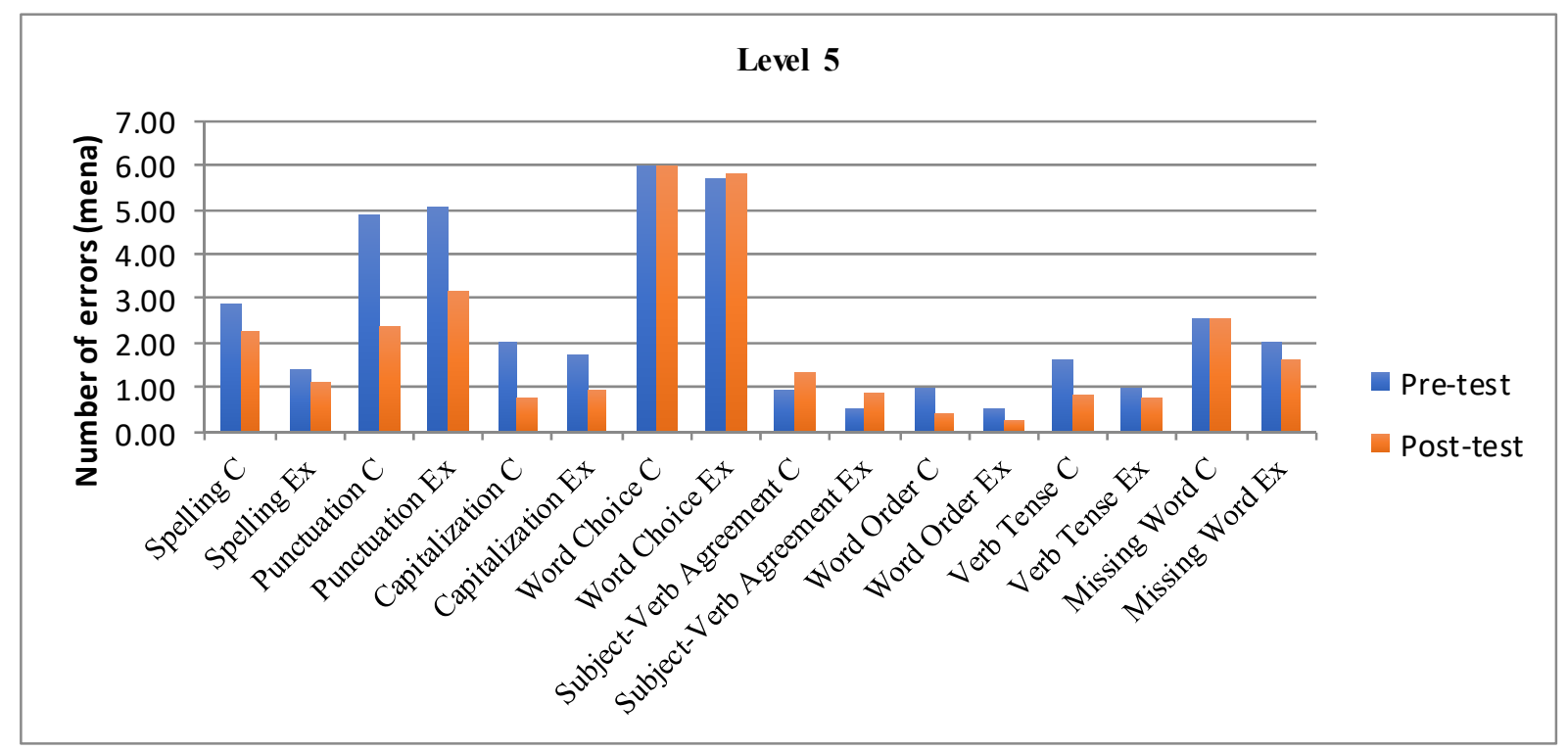

Figure 4. Linguistic competence criteria (level 5)

In relation to the evaluation criteria for linguistic competence, for most of the criteria the number of errors reduced; this shows that the use of authentic materials enhances intermediate students' ability to write cohesive texts. However, it is important to mention that this decrease was not statistically significant; see Figure 4.

\subsection{Qualitative Analysis}

\subsubsection{Students' Perception of Improvement}

Table 3. Students' perception of improvement (level 4)

\begin{tabular}{llllll}
\hline Students' Perception of Improvement & $\mathbf{5}$ (very high) & 4 (high) & 3 (average) & 2 (low) & 1 (very low) \\
\hline 1. Vocabulary & $12.5 \%$ & $50 \%$ & $37.5 \%$ & $0 \%$ & $0 \%$ \\
2. Grammatical Structures & $37.5 \%$ & $50 \%$ & $12.5 \%$ & $0 \%$ & $0 \%$ \\
3. Punctuation & $25 \%$ & $50 \%$ & $25 \%$ & $0 \%$ & $0 \%$ \\
4. Spelling & $25 \%$ & $50 \%$ & $25 \%$ & $0 \%$ & $0 \%$ \\
5. Reading Comprehension & $37.5 \%$ & $37.5 \%$ & $25 \%$ & $0 \%$ & $0 \%$ \\
6. Listening Comprehension & $25 \%$ & $25 \%$ & $50 \%$ & $0 \%$ & $0 \%$ \\
7. Oral Communication & $25 \%$ & $50 \%$ & $25 \%$ & $0 \%$ & $0 \%$ \\
8. Cultural Knowledge & $37.5 \%$ & $50 \%$ & $0 \%$ & $12.5 \%$ & $0 \%$ \\
\hline
\end{tabular}

In Level 4 (pre-intermediate level), a high percentage of students $(50 \%)$ thought that the use of authentic material in class led to a marked improvement in their vocabulary, grammatical structures, punctuation, spelling, reading comprehension, oral communication, and cultural knowledge. However, $50 \%$ felt that their listening comprehension improvement was not as high as the other parameters, and gave this skill an average grade.

Table 4. Students' perception of improvement (level 5)

\begin{tabular}{llllll}
\hline Students' Perception of Improvement & $\mathbf{5}$ (very high) & $\mathbf{4}$ (high) & $\mathbf{3}$ (average) & 2 (low) & 1 (very low) \\
\hline 1. Vocabulary & $40 \%$ & $53,33 \%$ & $6,66 \%$ & 0 & 0 \\
2. Grammatical Structures & $40 \%$ & $53,33 \%$ & $6,66 \%$ & 0 & 0 \\
\hline
\end{tabular}




\begin{tabular}{llllll}
\hline 3. Punctuation & $66,66 \%$ & $26,66 \%$ & 0 & $6,66 \%$ & 0 \\
4. Spelling & $60 \%$ & $26,66 \%$ & $13,33 \%$ & 0 & 0 \\
5. Reading Comprehension & $53,33 \%$ & $26,66 \%$ & $20 \%$ & 0 & 0 \\
6. Listening Comprehension & $26,66 \%$ & $60 \%$ & $6,66 \%$ & $6,66 \%$ & 0 \\
7. Oral Communication & $46,66 \%$ & $46,66 \%$ & $6,66 \%$ & 0 & 0 \\
8. Cultural Knowledge & $53,33 \%$ & $20 \%$ & $20 \%$ & $6,66 \%$ & 0 \\
\hline
\end{tabular}

In Level 5 (intermediate level) a high percentage of students (53.33\%) thought that the use of authentic material in class made a significant difference to their vocabulary and grammatical structures, and $60 \%$ felt the same regarding listening comprehension. This is understandable, since Sabet and Mahsefat (2012) concluded that students who received instruction with the aid of authentic materials performed much better in listening perception.

Moreover, they stated a notable difference in punctuation, spelling, reading comprehension, and cultural knowledge, with percentages ranging from $46.66 \%$ to $66.66 \%$. However, a small percentage of participants felt that their improvement in punctuation, listening comprehension, and cultural knowledge was low.

There was a higher perception of improvement in listening comprehension in intermediate students than in pre-intermediate students, which leads us to believe that the use of authentic materials would be more profitable for teaching intermediate students.

\subsubsection{Students Opinions' on the Use of Authentic Resources}

Level 4

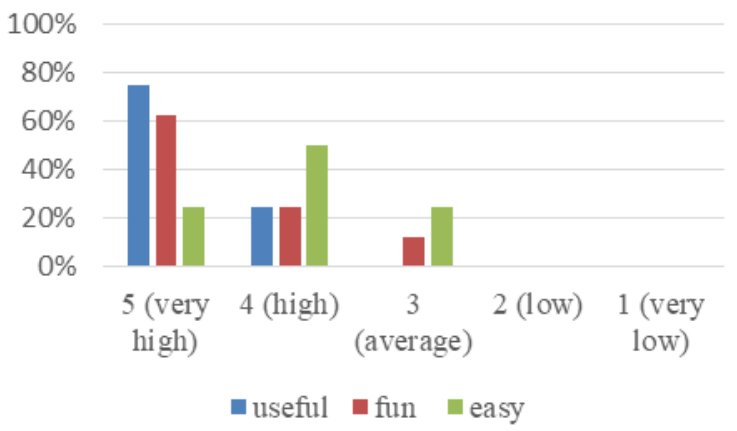

Level 5

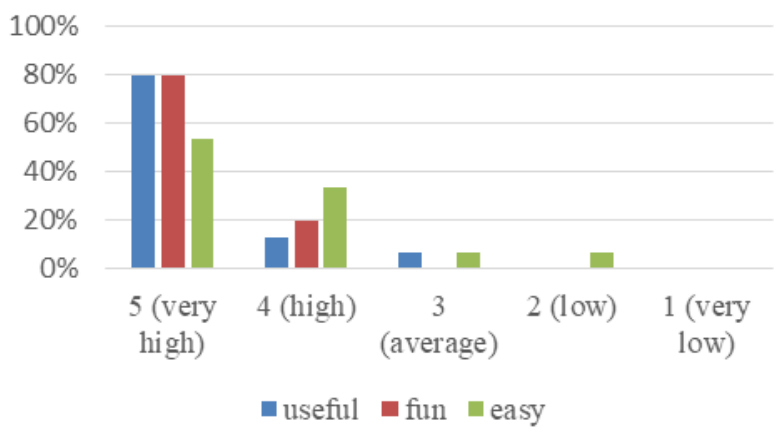

Figure 5. Videos

Figure 5. (Level 4) indicates the following results: $75 \%$ of students have a "very high" perception of video usefulness, $62.5 \%$ a "high" opinion of fun level, and 50\% a "high" rating for easiness.

Figure 5. (Level 5) shows the following results: $80 \%$ of students have a "very high" perception of video usefulness, $80 \%$ a "very high" opinion of fun level, and $53.33 \%$ a "very high" rating for easiness.

Both Level 4 and Level 5 students think that videos are very useful and fun. Moreover, these kinds of resources are easier for Level 5 than they are for Level 4.

In the EFL environment, students consider videos to be more "useful" and "fun" than they are "easy": "useful" because they learn new vocabulary and the types of words that come in handy in everyday interactions, and "fun" because they learn content at the same time as they unconsciously learn the language. This is in line with Krasnikova (2014) who thought that videos increase students' motivation and encourage them to learn new vocabulary. 
Level 4

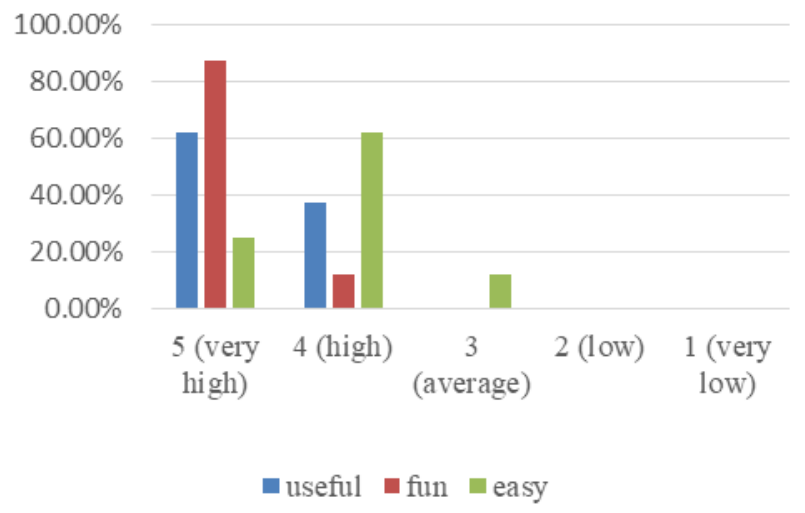

Level 5

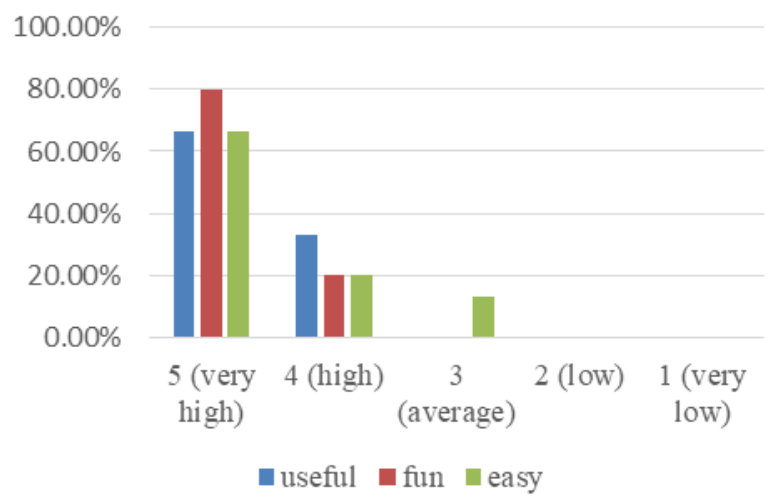

Figure 6. Movie segments

Figure 6. (Level 4) reveals the following results: $62.5 \%$ of students have a "very high" perception of the usefulness of movie segments, $87.5 \%$ a "very high" opinion of fun level, and $63 \%$ a "high" rating for easiness.

Figure 6. (Level 5) shows the following results: $66.66 \%$ of students have a "very high" perception of usefulness of movie segments, $80 \%$ a "very high" opinion of fun level, and $66.66 \%$ a "very high" rating for easiness.

Both Level 4 and Level 5 students express that the movie segments used in class are more fun than they are useful. Additionally, as was the case with videos, these kinds of resources are easier for Level 5 than they are for Level 4.

\section{Level 4}

\section{$100.0 \%$}

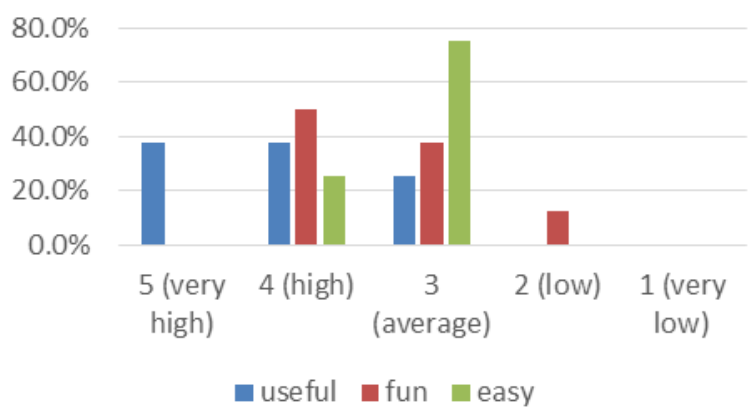

\section{Level 5}

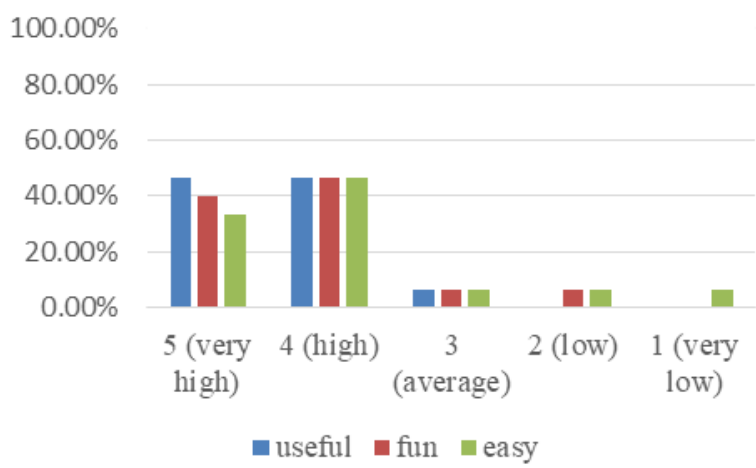

Figure 7. Written texts

Figure 7. (Level 4) illustrates the following results: $37.5 \%$ of students express a "very high" and $37.5 \%$ a "high" perception of the usefulness of written texts, $50 \%$ a "high" opinion of fun level, $75 \%$ an "average" rating for easiness.

Figure 7. (Level 5) shows the following results: $46.66 \%$ of students have a "very high" and $46.66 \%$ a "high" perception of the usefulness of written texts, $47 \%$ a "high" opinion of fun level, and $46.66 \%$ a "high" rating for easiness.

A higher percentage of level 5 students find written tests to be very useful and fun whereas for Level 4 students they are not as useful and fun as they are for Level 5. They are also easier for Level 5 students.

These positive attitudes towards outside materials that involve reading are consistent with previous study results. Akbari \& Razavi (2015) consider them helpful to develop students' language skills and expose them to real English language use. Likewise, Duff, Tomblin, and Catts (2015) confirmed that language vocabulary acquisition is more likely to happen through reading. 
Level 4

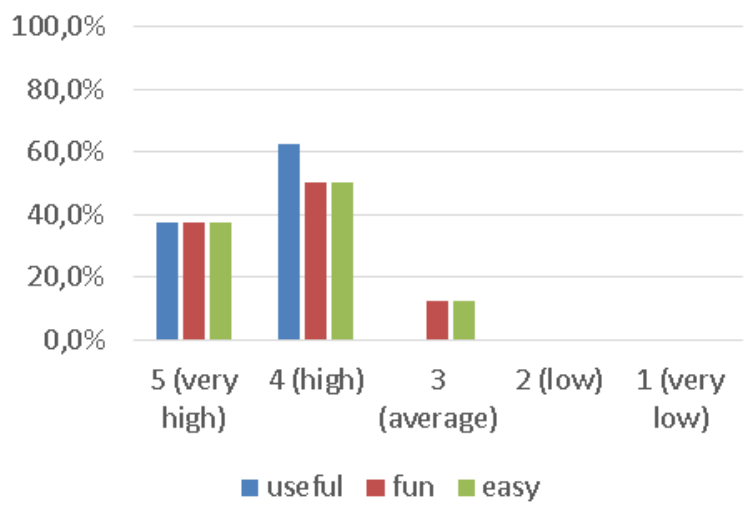

Level 5

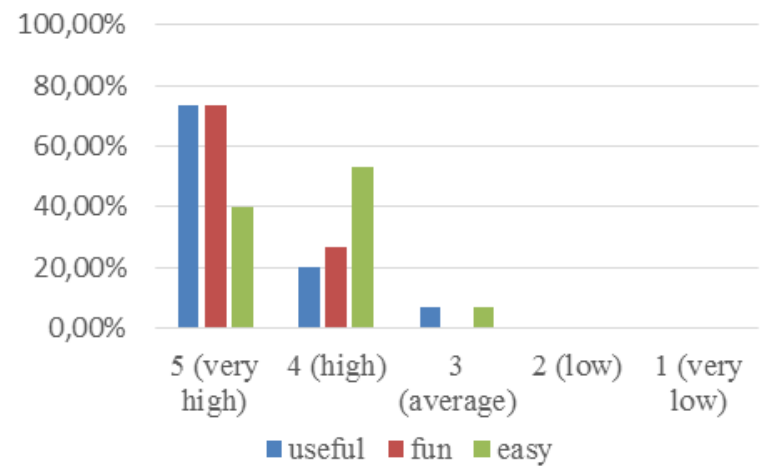

Figure 8. Songs

Figure 8. (Level 4) indicates the following results: $62.5 \%$ of student express a "high" perception of the usefulness of songs, $50 \%$ a "high" opinion of fun level, and 50\% a "high" rating for easiness.

Figure 8. (Level 5) shows the following results: $73.33 \%$ of students have a "very high" perception of the usefulness songs, $73.33 \%$ a "very high" opinion of fun level, and 53\% a "high" rating for easiness.

The songs were more useful and fun for level 5 students than for Level 4 students and the songs are easy for both.

(Shen, 2009) stated that the use of songs in the EFL classroom has positive effects, since students will view the activity as entertainment rather than work, making language learning fun and relaxed. Shen concluded that listening to songs reduces psychological barriers such as anxiety and lack of self-confidence.

\subsubsection{Student Comments Regarding the Activities They Enjoyed}

Level 4 Student Comments:

(1) The videos and movies because they helped me out understand better. (2) Loved the activity about doing yoga and at the same time explaining. (3) Loved watching movie segments and listening to songs because they assisted me in the process of learning vocabulary and verbal expressions. (4) I liked the movie of Julia Roberts because it was very useful and fun. I understood the activity and the grammatical structures. (5) I liked yoga in the class because it is something new and no common. (6) I liked the use of famous songs because I learned grammar tenses, so when I remember the song it reminds me of the tenses and it is easier that way. (7) The handouts of authentic materials were good because I could talk with my classmates, and I had to make an effort to explain certain topics that are very useful. (8) Watching movie segments or documentaries because I understood well and learnt at the same time because they were interesting.

Level 5 Student Comments:

(1) I loved watching funny videos because they caught my attention, and I practiced my English. (2) I liked the TV commercials because I had to think in English to find out what they were about. (3) I liked the activity with movie segments because they were interesting and very useful. (4) Watching the movie because I could improve my vocabulary. (5) The movie segments were entertaining and useful to improve the comprehension. (6) The activity with the TV commercials because they were entertaining. (7) Motivational videos because they helped me learn and at the same time, they left me a message. (8) Liked all the activities since this is fun way of learning. (9) I liked the movie segments because I learned a lot about general culture and vocabulary. (10) Watching videos because they helped me to enhance the listening comprehension, oral production, and cultural understanding. (11) The activity about the song because I had to explain what the lyrics meant through a picture. (12) Listening to a song and put in order adjectives, nouns, and verbs.

The participants felt that the use of songs helped them to acquire vocabulary and learn grammar tenses. This fits with the perception of Shen, who noted that songs help students learn grammar tenses; one example is the song "Lemon Tree" which helps students memorize the use of the present progressive (repeated many times in the song). Following this, students are able to use the grammar tense correctly in their own conversations. 
Questionnaire answers from the fourth and fifth levels reveal positive student attitudes towards activities with authentic materials in the EFL classroom. Participants from Level Four said that activities with such materials helped them understand the language better, aided them in the process of learning vocabulary, were useful and fun, helped them understand certain grammatical structures and grammar tenses, aided them in expressing themselves in English, and that they learnt content and the language at the same time. Overall, a majority of participants express positive opinions about the authentic materials, in particular the videos, movie segments, and songs.

Likewise, most Level Five students enjoyed input from activities that involved listening and watching — such as TV commercials, videos, and movie segments - because these kinds of resources caught students' attention, and helped them improve vocabulary, listening comprehension, oral production, and cultural understanding. In other words, they learnt both language and content.

\subsubsection{Student Comments Regarding the Activities They Disliked}

Level 4 Student Comments:

(1) I did not like the reading activities. It is necessary, though. (2) Some reading text were not interesting enough, so I lost motivation and did not learn that much. (3) Writing after each reading activity because it turned monotonous. (4) I did not like the activity of figuring out the meaning of unknown words after a reading activity because there were complex words and it took too much time to find out the meaning of those words. (5) I did not like filling out in the listening activities because I could get the idea of the listening but not specific vocabulary words.

Level 5 Student Comments:

(1) I didn't like the activity of listening and describing because the listening was not clear. (2) I didn't like the activities of reading because they had unknown vocabulary. (3) I didn't like the activities that involve speaking because I am shy and don't like speaking in public. (4) Reading because sometimes I didn't understand the text. (5) One listening activity because it was not clear. (6) Reading texts because that is a common activity.

Focusing on the activities disliked by students, we identified that a few participants were hesitant about certain reading and listening activities that included complex vocabulary words, and they struggled to understand some speech delivery because they were neither accustomed to listening to different types of accents nor to native English speakers. It can be assumed that this situation varies depending on the students' vocabulary level and general reading and listening abilities. However, as is noted by the University of Oregon in the video "Shaping the Way We Teach English" (UOregon, 2009), the written pieces of text to be used the EFL classrooms must have a "usable language style, good quality picture and sound, and be of interest to the age group." In this regard, it is necessary to keep these factors in mind when selecting materials to avoid loss of motivation and difficulties learning the language.

\section{Conclusions}

This study found that pre-intermediate level students improved in one of the parameters for communicative competence - clarity/organization (coherence) - a conclusion supported by the statistically significant differences. Moreover, it was noted that while there was no statistically significant difference in linguistic competence, the number of errors in punctuation, word choice, and verb tense decreased. On the other hand, intermediate students improved in both communicative competence (relevance, clarity/organization) and linguistic competence (most parameters): that is, coherence and cohesion. However, this improvement is not supported by a statistically significant difference.

On the subject of students' perception regarding their own improvement, we found that pre-intermediate level students felt they improved on vocabulary, grammatical structures, punctuation, spelling, oral communication, and cultural knowledge skills at a high rate. Students' perception of their reading comprehension skill was divided between a very high and a high rate, and listening comprehension was rated with only an average rate. On the other hand, a high percentage of intermediate level participants felt that their punctuation, spelling, reading comprehension, oral communication and cultural knowledge skills improved at very high and high rates. It can thus be noted there is a very high/high perception of improvement for most of the parameters following the use of authentic materials. These findings apply to both pre-intermediate and intermediate students. However, it is clearly shown that this perception is higher in Level 5 than in Level 4. Another aspect that was noted is that Level 4 students felt their listening comprehension improvement to be lower than they would have expected.

As far as students' opinions regarding the different types of authentic resources used in the classroom, a high percentage considered these resources to be helpful, fun, and easy to use (it was noted that intermediate 
participants had a higher opinion of them, however). This study thus provides support for the use of authentic materials in the EFL classroom. Though, students' performance was not as high as expected, it was noted that the learners from the experimental groups performed much better than the control groups. Additionally, since they were able to understand the main idea of most of the authentic resources used, a vast majority of the participants increased their self-confidence with using English to communicate. This caused their overall motivation to, in turn, increase.

In summary, the participants improved their coherence, cohesion, and cultural understanding, as well as their language proficiency level in terms of appropriate lexical and syntactical use. They likewise developed their cognitive skills because they had to pay attention to input from authentic resources and then use the prompt given to work on creative writing pieces.

\section{Study Limitations}

These conclusions are based on the use of authentic materials during $50 \%$ of 2 hour-long daily classes. While our results are positive, it is advisable that these resources be applied $100 \%$ of the time, so that the findings can reflect the participants' general learning experience and improvement in writing skills.

The purpose of the study was to determine the benefits of authentic resources on pre-intermediate and intermediate language learners in regard to coherence and cohesion. Since there is a favorable impact on writing skill development in both levels, there is a need to investigate how effective these materials are in encouraging other skills, such as reading and listening comprehension.

\section{Acknowledgements}

This project achieved its aims thanks to the help and assistance of many people, and we feel immensely privileged to mention them upon the finalization of the first part of our research - particularly since our objective is now to continue our study with reading and listening skills.

We thank the Pontifical Catholic University of Ecuador for providing us with the opportunity to undertake and complete the project which culminated with this article. We are also thankful to our students, who were participants in our research.

We would also like to respectfully acknowledge our editor, Kimrey Batts, and of course, Alan Jaramillo, without whose help the elaboration of the statistical tables found in the appendices would have been far more difficult, as we are not experts in this area.

\section{References}

Abdul, T., Rahman, A., Sabri, M., \& Shukri, M. (2017, May). A Review of Documentary Film as Authentic Input in Enhancing Writing Skills in Asl Setting. Retrieved from Journal of Nusantara Studies (JONUS): Retrieved from https://journal.unisza.edu.my/jonus/index.php/jonus/article/view/16/38

Adam, S. L., Stan, R. S., Moanga, A. S., Oroian, E., Mihai, M., \& Ciubancan, M. (2010). The role of authentic materials in foreign language teaching. Bulletin UASVM Horticulture, 67(2), 431-435.

Akbari, O., \& Razavi, A. (2015, Junio 17). International Journal of Research Studies in Education. Using authentic materials in the foreign language. https://doi.org/10.5861/ijrse.2015.1189

Al Azri, R. H., \& Al-Rashdi, M. H. (2014). The effect of using authentic materials in teaching. International Journal of Scientific \& Technology Research, 249-254.

Al, S. (2003). Utilising Fiction to Promote English Language Acquisition . Cambridge Scholars Publishing.

Arianie, M. (2017). Authentic material and interactive activities in EFL classroom. English Franca, 1(2), 115-134. https://doi.org/10.29240/ef.v1i2.289

Belet Boyaci, S. D., \& Güner, M. (2018). The Impact of Authentic Material Use on Development of the Reading Comprehension, Writing Skills and Motivation In Language Course. International Journal of Instruction, 11(2), 351-368. https://doi.org/10.12973/iji.2018.11224a

Bublitz, W., Lenk, U., \& Ventola, E. (1997). Coherence in Spoken and Written Discourse : How to create it and how to describe it. Selected papers from the International Workshop on Coherence, Augsburg, 24-27 April 1997. John Benjamins Publishing Company.

Chamba, M., \& Gavilanes, C. (2018). Authentic Audio-Visual Material in the Development of Oral Fluency in University Intermediate English Students.

Creme, P., \& Lea, M. R. (2008). Writing At University: A Guide For Students. 
Crossley, S. A., Louwerse, M. M., McCarthy, P. M., \& McNamara, D. S. (2007). A Linguistic Analysis of Simplified and Authentic Texts. The Modern Language Journal, 91(1), 15-30. https://doi.org/10.1111/j.1540-4781.2007.00507.x

Duff, D., Tomblin, B., \& Catts, H. (2015, June). Journal of Speech, Language, and Hearing Research. Retrieved from The Influence of Reading on Vocabulary Growth: A Case for a Matthew Effect. https://doi.org/10.1044/2015_JSLHR-L-13-0310

Educación, M. d. (2016). Lengua Extranjera. Retrieved from https://educacion.gob.ec/curriculo-lengua-extranjera/

EF-EPI. (2018). EF English Proficiency Index. Retrieved from https://www.ef.com.ec/epi/

Guariento, W., \& Morley, J. (2001). Text and task authenticity in the EFL classroom. ELT Journal, 55(4), 347-353. https://doi.org/10.1093/elt/55.4.347

Harutyunyan, L., \& Poveda, M. F. (2018). Students' perception of peer review in an EFL classroom. English language teaching, 11(4), 138-149. https://doi.org/10.5539/elt.v11n4p138

Hinkel, E. (2003). Teaching Academic ESL Writing: Practical Techniques in Vocabulary and Grammar. Routledge. https://doi.org/10.4324/9781410609427

Jason, T. (2011). Speak: A Short History of Languages. Oxford University Press.

Joy, J. L. (2011). The Duality of Authenticity in ELT. The Journal of Language and Linguistic Studies, 7(2), $7-23$.

Krasnikova, I. (2014, Abril 21). University of Alberta Libraries. Retrieved from Film as a Source of Authentic Material in Teaching ESL Writing. Retrieved from https://era.library.ualberta.ca/items/ede2f517-b164-4b65-92d5-11a5ae9c036a

Lawe Davies, R. (1999). How do we define and teach 'relevance' in academic writing? In K. Martin, N. Stanley, \& N. Davison (Eds.), Teaching in the Disciplines/ Learning in Context (pp. 220-223). Proceedings of the 8th Annual Teaching Learning Forum, The University of Western Australia, February 1999. Perth: UWA.

Mishan, F. (2005). Designing authenticity into language learning materials. Bristol, UK: Intellect Books.

Nematollahi, S., \& Maghsoudi, M. (2015). The effect of authentic versus non-authentic texts on upper intermediate Iranian EFL learners' vocabulary retention. English Language Teaching, 8(12), 112-123. https://doi.org/10.5539/elt.v8n12p112

Nordquist, R. (2018, January). ThoughtCo.: What Is Clarity in Composition? Retrieved from https://www.thoughtco.com/what-is-clarity-composition-1689847

Richard, J., \& Rodgers, T. (2001). Approaches and Methods in Language Learning. CUP. https://doi.org/10.1017/CBO9780511667305

Sabet, M., \& Mahsefat, H. (2012, Septiembre 1). International Journal of Applied Linguistics and English Literature. The Impact of Authentic Listening Materials on Elementary EFL Learners' Listening Skills. https://doi.org/10.7575/ijalel.v.1n.4p.216

Shen, C. (2009, March). English Language Teaching. Retrieved from Using English Songs: An Enjoyable and Effective Approach to ELTUsing English Songs: An Enjoyable and Effective Approach to ELT. https://doi.org/10.5539/elt.v2n1p88

Sundana, G. P. (2017). The use of authentic material in teaching writing descriptive text. English Review: Journal of English Education, 6(1), 81-88. https://doi.org/10.25134/erjee.v6i1.773

Tanskanen, S.-K. (2006). Collaborating towards Coherence : Lexical cohesion in English discourse. John Benjamins Publishing Company. https://doi.org/10.1075/pbns.146

UOregon. (2009, January). Shaping the Way We Teach English: Module 08, Authentic Materials. Retrieved from https://www.youtube.com/watch?v=8mgwWhWa0Q8

Yuhong, J. (2012). Reflection, Change, and Reconstruction in the Context of Educational Reform and Innovation in China: Towards an Integrated Framework Centred on Reflective Teaching Practice for EFL Teachers' Professional Development. Newcastle upon Tyne, NE6 2XX, UK: Cambridge Scholars Publishing. 


\section{Appendices}

\section{Appendix 1}

\begin{tabular}{|c|c|c|c|c|c|c|c|c|c|c|c|c|c|}
\hline \multicolumn{14}{|c|}{ LEVEL 4 PRE-TEST } \\
\hline \multicolumn{2}{|l|}{ Group } & Relevance & $\begin{array}{c}\text { Clarity } \\
\text { Organization }\end{array}$ & Spelling & Punctuation & Capitalization & Wrong Word & $\begin{array}{c}\text { Subject Verb } \\
\text { agreement }\end{array}$ & Word Order & Verb Tense & $\begin{array}{c}\text { Insert } \\
\text { Something }\end{array}$ & Total Grade & $\begin{array}{c}\text { Numer of } \\
\text { Errors }\end{array}$ \\
\hline \multirow[t]{4}{*}{ Control } & Media & 2,6000 & 3,9000 & 2,3000 & 6,8000 & 3,3000 & 5,6000 & 0,2000 & 0,2000 & 3,0000 & 2,3000 & 6,3000 & 23,7000 \\
\hline & Mínimo & 1,00 & 2,00 & 0,00 & 4,00 & 1,00 & 0,00 & 0,00 & 0,00 & 1,00 & 1,00 & 4,50 & 11,00 \\
\hline & Máximo & 4,00 & 6,00 & 7,00 & 10,00 & 8,00 & 10,00 & 1,00 & 1,00 & 6,00 & 5,00 & 9,00 & 31,00 \\
\hline & \begin{tabular}{|l} 
Desviación \\
estándar
\end{tabular} & 0,96609 & 1,28668 & 2,62679 & 2,14994 & 2,40601 & 3,13404 & 0,42164 & 0,42164 & 1,69967 & 1,56702 & 1,37840 & 6,75031 \\
\hline \multirow[t]{4}{*}{ Experimental } & Media & 2,6000 & 4,0000 & 2,0000 & 8,4000 & 2,0000 & 11,5000 & 0,2000 & 0,3000 & 3,4000 & 2,5000 & 6,2500 & 30,3000 \\
\hline & Mínimo & 2,00 & 2,00 & 0,00 & 2,00 & 0,00 & 4,00 & 0,00 & 0,00 & 0,00 & 0,00 & 4,00 & 14,00 \\
\hline & Máximo & 3,00 & 5,00 & 4,00 & 17,00 & 4,00 & 25,00 & 2,00 & 1,00 & 9,00 & 10,00 & 8,00 & 51,00 \\
\hline & \begin{tabular}{|l} 
Desviación \\
estándar
\end{tabular} & 0,51640 & 1,05409 & 1,15470 & 5,01553 & 1,49071 & 6,86780 & 0,63246 & 0,48305 & 2,75681 & 3,02765 & 1,33853 & 12,70214 \\
\hline
\end{tabular}

\section{Appendix 2}

\begin{tabular}{|c|c|c|c|c|c|c|c|c|c|c|c|c|c|}
\hline \multicolumn{14}{|c|}{ LEVEL 4 POST-TEST } \\
\hline \multicolumn{2}{|l|}{ Group } & Relevance & $\begin{array}{c}\text { Clarity } \\
\text { Organization }\end{array}$ & Spelling & Punctuation & Capitalization & Wrong Word & \begin{tabular}{|c|} 
Subject Verb \\
agreement
\end{tabular} & Word Order & Verb Tense & $\begin{array}{c}\text { Insert } \\
\text { Something }\end{array}$ & Total Grade & $\begin{array}{l}\text { Numer of } \\
\text { Errors }\end{array}$ \\
\hline \multirow[t]{4}{*}{ Control } & Media & 2,2500 & 3,9500 & 1,8000 & 7,6000 & 1,8000 & 8,5000 & 0,4000 & 0,5000 & 3,1000 & 1,3000 & 6,1200 & 25,0000 \\
\hline & Mínimo & 1,50 & 2,00 & 0,00 & 1,00 & 0,00 & 3,00 & 0,00 & 0,00 & 0,00 & 0,00 & 4,00 & 8,00 \\
\hline & Máximo & 3,00 & 5,00 & 5,00 & 14,00 & 3,00 & 21,00 & 2,00 & 2,00 & 8,00 & 4,00 & 8,00 & 42,00 \\
\hline & $\begin{array}{l}\text { Desviación } \\
\text { estándar }\end{array}$ & 0,58926 & 1,01242 & 2,04396 & 3,83551 & 1,22927 & 6,81909 & 0,69921 & 0,70711 & 2,42441 & 1,33749 & 1,45663 & 12,18378 \\
\hline \multirow[t]{4}{*}{ Experimental } & Media & 2,6000 & 4,8000 & 1,9000 & 6,4000 & 1,7000 & 8,6000 & 0,2000 & 0,9000 & 2,7000 & 2,1000 & 6,8500 & 24,5000 \\
\hline & Mínimo & 1,00 & 4,00 & 0,00 & 0,00 & 0,00 & 2,00 & 0,00 & 0,00 & 0,00 & 0,00 & 5,00 & 8,00 \\
\hline & \begin{tabular}{|l|} 
Máximo \\
\end{tabular} & 3,00 & 6,00 & 9,00 & 16,00 & 7,00 & 15,00 & 1,00 & 2,00 & 7,00 & 5,00 & 9,00 & 45,00 \\
\hline & $\begin{array}{l}\text { Desviación } \\
\text { estándar }\end{array}$ & 0,69921 & 0,63246 & 2,60128 & 4,47710 & 2,00278 & 4,52647 & 0,42164 & 0,73786 & 2,45176 & 2,02485 & 1,29207 & 11,02774 \\
\hline
\end{tabular}


Appendix 3

\begin{tabular}{|c|c|c|c|c|c|c|c|c|c|c|c|c|c|}
\hline \multicolumn{14}{|c|}{ LEVEL 5 PRE-TEST } \\
\hline \multicolumn{2}{|l|}{ Group } & Relevance & $\begin{array}{c}\text { Clarity } \\
\text { Organization }\end{array}$ & Spelling & Punctuation & Capitalization & Wrong Word & $\begin{array}{r}\text { Subject Verb } \\
\text { agreement }\end{array}$ & Word Order & Verb Tense & $\begin{array}{c}\text { Insert } \\
\text { Something }\end{array}$ & Total Grade & $\begin{array}{l}\text { Numer of } \\
\text { Errors }\end{array}$ \\
\hline \multirow[t]{4}{*}{ Control } & Media & 3,6875 & 5,2813 & 2,8750 & 4,8750 & 2,0000 & 6,0000 & 0,9375 & 1,0000 & 1,6250 & 2,5625 & 8,0438 & 21,8750 \\
\hline & Mínimo & 2,00 & 2,00 & 0,00 & 1,00 & 0,00 & 2,00 & 0,00 & 0,00 & 0,00 & 0,00 & 4,00 & 11,00 \\
\hline & Máximo & 4,00 & 6,00 & 6,00 & 9,00 & 5,00 & 12,00 & 6,00 & 6,00 & 6,00 & 7,00 & 9,20 & 38,00 \\
\hline & $\begin{array}{l}\text { Desviación } \\
\text { estándar }\end{array}$ & 0,70415 & 0,99948 & 2,41868 & 2,15639 & 1,26491 & 2,58199 & 1,61116 & 1,71270 & 1,58640 & 2,03204 & 1,18770 & 6,20618 \\
\hline \multirow[t]{4}{*}{ Experimental } & Media & 3,0000 & 4,4688 & 1,3750 & 5,0625 & 1,7500 & 5,6875 & 0,5000 & 0,5000 & 1,0000 & 2,0000 & 7,3250 & 17,8750 \\
\hline & Mínimo & 2,00 & 3,00 & 0,00 & 0,00 & 0,00 & 0,00 & 0,00 & 0,00 & 0,00 & 0,00 & 5,00 & 1,00 \\
\hline & Máximo & 4,00 & 6,00 & 5,00 & 12,00 & 5,00 & 14,00 & 2,00 & 2,00 & 6,00 & 8,00 & 9,70 & 38,00 \\
\hline & \begin{tabular}{|l|} 
Desviación \\
estándar
\end{tabular} & 0,65828 & 1,04033 & 1,62788 & 3,41504 & 1,65328 & 3,75444 & 0,63246 & 0,63246 & 1,63299 & 2,55604 & 1,50222 & 11,01438 \\
\hline
\end{tabular}

\section{Appendix 4}

\begin{tabular}{|c|c|c|c|c|c|c|c|c|c|c|c|c|c|}
\hline \multicolumn{14}{|c|}{ LEVEL 5 POST-TEST } \\
\hline \multicolumn{2}{|l|}{ Group } & Relevance & $\begin{array}{c}\text { Clarity } \\
\text { Organization }\end{array}$ & Spelling & Punctuation & Capitalization & Wrong Word & $\begin{array}{c}\text { Subject Verb } \\
\text { agreement }\end{array}$ & Word Order & Verb Tense & $\begin{array}{c}\text { Insert } \\
\text { Something }\end{array}$ & Total Grade & $\begin{array}{c}\text { Numer of } \\
\text { Errors }\end{array}$ \\
\hline \multirow[t]{4}{*}{ Control } & Media & 2,9375 & 4,9063 & 2,2500 & 2,3750 & 0,7500 & 6,0000 & 1,3125 & 0,4375 & 0,8125 & 2,5625 & 7,6188 & 16,5000 \\
\hline & Minimo & 2,00 & 3,00 & 0,00 & 0,00 & 0,00 & 2,00 & 0,00 & 0,00 & 0,00 & 0,00 & 5,00 & 4,00 \\
\hline & Máximo & 3,50 & 6,00 & 5,00 & 4,00 & 2,00 & 15,00 & 4,00 & 3,00 & 3,00 & 6,00 & 8,50 & 32,00 \\
\hline & \begin{tabular}{|l} 
Desviación \\
estándar
\end{tabular} & 0,51235 & 0,86060 & 1,73205 & 1,08781 & 0,85635 & 3,96653 & 1,01448 & 0,81394 & 0,98107 & 1,96532 & 1,08334 & 7,66812 \\
\hline \multirow[t]{4}{*}{ Experimental } & Media & 3,1250 & 5,1250 & 1,1250 & 3,1875 & 0,9375 & 5,8125 & 0,8750 & 0,2500 & 0,7500 & 1,6250 & 7,9688 & 14,5625 \\
\hline & Mínimo & 2,00 & 3,00 & 0,00 & 0,00 & 0,00 & 1,00 & 0,00 & 0,00 & 0,00 & 0,00 & 5,00 & 6,00 \\
\hline & Máximo & 3,50 & 5,50 & 6,00 & 8,00 & 4,00 & 17,00 & 4,00 & 1,00 & 4,00 & 5,00 & 9,00 & 27,00 \\
\hline & \begin{tabular}{|l|} 
Desviación \\
estándar
\end{tabular} & 0,42817 & 0,61914 & 1,62788 & 2,25740 & 1,12361 & 4,36988 & 1,08781 & 0,44721 & 1,18322 & 1,54380 & 0,97756 & 6,47012 \\
\hline
\end{tabular}

\section{Copyrights}

Copyright for this article is retained by the author(s), with first publication rights granted to the journal.

This is an open-access article distributed under the terms and conditions of the Creative Commons Attribution license (http://creativecommons.org/licenses/by/4.0/). 